\title{
A maxilla front régiójában elhelyezkedő nagy kiterjedésú radikuláris ciszta komplex ellátása
}

\author{
Esetismertetés
}

DR. SZEKERES GYÖRGYI, DR. WÜRSCHING TAMÁS*, DR. NEMES JÚLIA, DR. TÓTH ZSUZSANNA

\begin{abstract}
Az állcsontciszták legnagyobb részét a radikuláris ciszták teszik ki. A radikuláris ciszták mindig gyulladás talaján alakulnak ki, ezért fontos, hogy a gyulladás kiváltó okát is kezeljük. A fogakkal összefüggésben lévő cisztás elváltozások esetén az érintett fogak extrakciója vagy a fogak gyökérkezelése szükséges. A bemutatott 77 éves, II. típusú diabéteszben szenvedő férfi páciens esete endodonciai és szájsebészeti ellátást igényelt, ezek a kezelések párhuzamosan és egymást kiegészítve zajlottak. A páciens kora és egészségi állapota ellenére a cisztektómiás üreg jó csontregenerációt mutatott. A kezelés megkezdését követő hetedik hónapra a ciszta által okozott csontlézió jelentősen csökkent, egy év alatt pedig teljesen reosszifikálódott.
\end{abstract}

Kulcsszavak: gyökérkezelés, radikuláris ciszta, cisztektómia, cisztosztómia, dekompresszió

\section{Bevezetés}

Az állcsontokban a cisztaképződés rendkívül gyakori jelenség. $A$ hámbélésük eredetétől függően megkülönböztetünk odontogén és nem odontogén állcsontcisztákat.

A ciszták létrejöttének patogenezisét már régóta vizsgálják, de a folyamat még nem teljesen tisztázott. A ciszták kialakulásának három állomása van. Első lépésként a nyugvó epithel sejtek proliferálni kezdenek a gyulladás miatt termelődő citokinek és növekedési faktorok hatására. A második fázisban epithel sejtek által határolt üreg képződik, ennek a mechanizmusa nem teljesen ismert. Az üreg képződésére két lehetséges teória van. Az egyik a „központi nekrózis teória”, amely szerint a hám a proliferációja miatt olyan vastagságot ér el, aminél a központi sejtek már nem kapnak elegendő tápanyagot, ezért nekrózison és apoptózison mennek keresztül. A ciszta képződő üregét degenerálódó epithel sejtek, leukocyták és szöveti folyadék tölti ki. A másik elmélet, az „abscessus teória” szerint az epithel sejtek körbenőnek egy gyulladásos gócot vagy egy nekrotizált kötőszövetes részt. Jelenleg azt feltételezik, hogy az epithel sejtek egy 3 dimenziós hálózatot alkotnak, ilyen módon csapdába ejtve egy gyulladásos kötőszövet-szigetet, amelynek emiatt megszakad az érellátása, a terület pedig elhal $[5,6]$.

Az odontogén ciszta: foggal kapcsolatban lévő, csontban elhelyezkedő, kötőszövetes tokkal körülvett, hámmal bélelt tömlő, amelynek üregét szalmasárga színü, híg szerózus jellegű folyadék tölti ki. Az elváltozás falát képező epithel sejtek a Malassez-féle hámszigetekből származnak. Az odontogén ciszták gyulladás talaján vagy fejlődési rendellenességgel összefüggésben alakulnak ki [3]. Panaszokat a ciszták a legtöbb esetben a ciszta felülfertőződése miatt okoznak, de sokszor tünetmentesen növekednek és csak mellékleletként kerülnek felfedezésre. Növekedésük során nem infiltrálják a környező szöveteket, nem minősülnek daganatnak, bár talajukon kialakulhat daganatos megbetegedés. Expanziójukért a szemipermeábilis hámbélés által termelt folyadék hidrosztatikus nyomása felelős [7]. A növekedő ciszta nyomást fejt ki a környező szövetekre, a csont pedig a folyamatos nyomásra felszívódással reagál. Növekedésük során a szomszédos fogakat diszlokálhatják, vagy a ciszta feletti csontterület elöredomborodását, esetenként külső gyökérreszorpciót okozhatnak. A nagyméretű ciszta esetén a maxillában, illetve mandibulában patológiás törések is előfordulhatnak. A növekedő ciszta a perifériás idegek nyomása révén neuralgiaform fájdalmat is kiválthat [12].

\section{Radikuláris ciszták}

Az odontogén állcsont ciszták közül a leggyakoribb a ciszta radikuláris. Legtöbbször 30-40 éves felnőttekben fordul elő. Nemi megoszlás szempontjából nem jelentős a különbség, de valamivel gyakoribb férfiakban. Lokalizáció szerint kiemelt terület a maxilla anterior régiója, 
ezt követi a mandibula posterior régiója, majd a felső állcsont hátsó területe. Legritkábban az alsó állcsont elülső területén fordul elő $[1,2,8,9,14]$. Radikuláris ciszta nekrotikus pulpájú, illetve gyökérkezelt fogak gyökércsúcsa körül fejlődhet ki. Ez a típusú csontelváltozás mindig gyulladás talaján alakul ki. Nem tisztázott azonban, hogy mikor alakul ki periapikális granuloma és mikor periapikális ciszta [3]. Az érintett fogak kopogtatásra, ráharapásra érzékenyek lehetnek, szenzitivitás vizsgálat során hidegre nem reagálnak. Ha a ciszta gyökértömött fogból indul ki, a röntgenvizsgálat során inkomplett gyökértöméssel vagy a koronális lezárás hiányával találkozunk. Ritkább esetekben radiológiailag kifogástalan gyökértömések mellett is kifejlődhet. Kialakulhat fogszuvasodás vagy baleset következtében nekrotizált pulpájú fogakon is. A röntgenfelvételen kerekded vagy ovoid elváltozás látható néhány $\mathrm{mm}$-től akár több centiméterig terjedő átmérővel. A szomszédos fogak gyökereit a ciszta széttolhatja, az érintett fog gyökerén pedig hosszabb fennállás következtében rezorpció alakulhat ki. Röntgenfelvételek alapján az elváltozás nagyságából és alakjából gyakran következtetünk arra, hogy az elváltozás ciszta vagy granulóma, de pontos diagnózis csak szövettani vizsgálat alapján állítható fel. A radikuláris ciszták hámbélése a szövettanilag többrétegű, el nem szarusodó laphám. A ciszta falában vegyes sejtes gyulladásos reakció látható, a hámot elsősorban neutrofil limfociták, a kötőszövetet limfociták és plazmasejtek infiltrálják [11].

\section{Ciszták kezelése}

A pontos diagnózis alapvető jelentőségú a kezelési terv felállításában. Nagyméretű granulómák esetén elegendő a fogat a szakma szabályainak megfelelő gyökértöméssel ellátni, míg egy valódi ciszta esetén nem remélhetjük az elváltozás gyógyulását sebészi beavatkozás nélkül. Bár egyes szerzők beszámolnak cisztaszerü elváltozások gyógyulásáról kizárólag konzerváló fogászati kezelés hatására, ezekben az esetekben, mivel nem vettek mintát a ciszta hámjából, a feltételezés nem is volt igazolható szövettanilag $[10,15]$. Abban azonban a legtöbb cikk megegyezik, hogy az érintett fogak mielőbbi gyökérkezelése előfeltétele a ciszta gyorsabb gyógyulásának. Gangwar és munkatársai azt javasolják, hogy ha ciszta mérete nagy, hosszabb ideig alkalmazzunk kalcium-hidroxid lezárást, az anyag rendszeres cseréjével [4]. A gyökértömés nem végezhető el addig, amíg a csatorna nem szárítható ki. A gyökércsatorna megnyitásával elérjük a cisztán belüli nyomás csökkenését, a rendszeres átöblítés segíti a csíraszám csökkenését, a gyökércsatorna fertőtlenítését. A kalcium-hidroxid antibakteriális hatású, a lúgos kémhatás ellensúlyozza a gyulladás savas kémhatását, a kalcium ionok pedig segítik a csontregenerációt. A fog végleges gyökértömése minden esetben a cisztektómia mútét előtt szükséges [10, 15, 16].
A ciszták kezelése során minden esetben szükség van szájsebészeti beavatkozásra is. A ciszta méretétől függően két beavatkozás jöhet szóba. Körülbelül 2 centiméter átmérőnél kisebb ciszták esetén az elváltozást egyben, a tokkal együtt kell eltávolítani. Ennél nagyobb átmérőnél nem javasolt cisztektómia mútét végzése, mert a véralvadék retrakciója miatt a savó által kitöltött terület a szájüreg felől fertőződhet, ezért per primam gyógyulásra nem számíthatunk. Nagy kiterjedésű ciszták esetén cisztosztómia műtét végzése javasolt, melynek során a cisztát a szájüreg vagy orrüreg melléküregévé alakítják [3].

Ez történhet a ciszta tokjának részleges vagy teljes eltávolításával. Az eredeti anatómiai viszonyok ennél a mútétnél lassan, gyakran évek alatt állnak helyre, és gyakori, hogy a regeneráció nem teljes. Ha az elváltozás mérete túl nagy a cisztektómia mútét elvégzé séhez, lehetőség van dekompressziós mútétre. Ennek a beavatkozásnak a célja a ciszta belső nyomásának csökkentése, ami elősegíti a csont regenerációját. A mútét után a ciszta üregét drenálják, ezt követően készülhet a páciens számára egy cisztaszúkítő. A szakirodalmi esetismertetések alapján a cisztaszúkítő viselésének javasolt ideje 5 héttől 2 évig terjedhet. A csontregenerációt röntgenfelvételeken kell követni és amikor eléri a megfelelő méretet, javasolt elvégezni a cisztektómia mútétet $[7,12,13]$.

\section{Esetismertetés}

A 77 éves férfi páciens 2010 májusában beutalóval érkezett a SE Konzerváló Fogászati Klinikájára az Arc-, Állcsont-, Szájsebészeti és Fogászati Klinikáról. A szájsebészeten készült OP felvételen a 11, 21, 22 fogak gyökércsúcsait magába foglaló, nagyméretú, kerekded radiolucens elváltozás látszott (1. ábra), ami radikuláris ciszta diagnózisát valószínúsítette. A páciens általános anamnézisében II típusú cukorbetegség szerepelt, amit gyógyszerrel és diétával kezeltek. A sztomato-

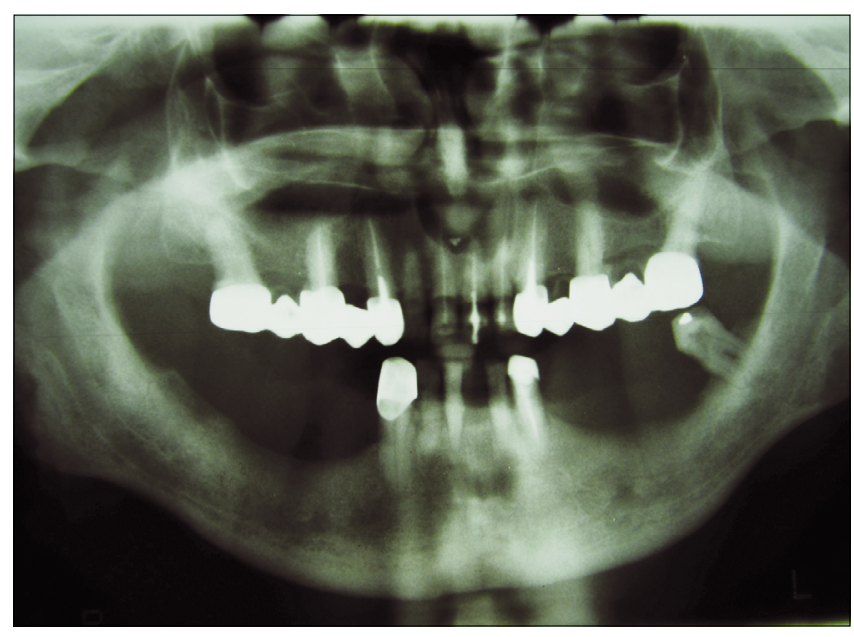

1. ábra: Kiindulási Op felvétel (2010. május 3.) 


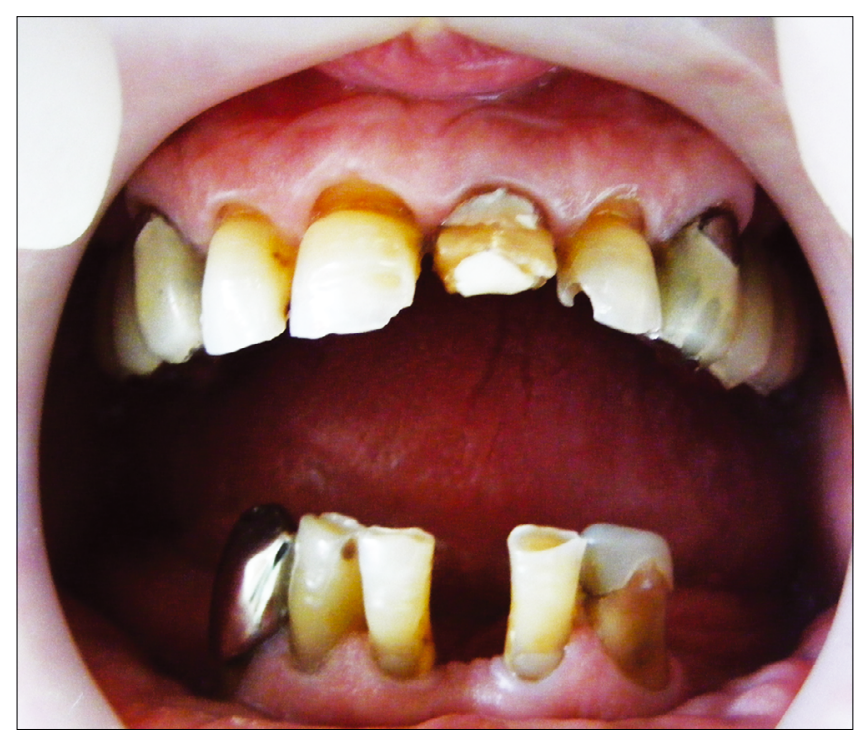

2. ábra: Száj fotó

onkológiai szűrővizsgálat során rákmegelőző állapotra utaló jel nem volt. A páciens a felső fogainál ráharapásra jelentkező fájdalomról számolt be. Klinikai vizsgálat alapján a páciens szájhigiénéje nem volt megfelelő, a felső állcsonton lévő hídpótlások alatt jelentős menynyiségű fogkő volt látható. (2. ábra) A felső állcsonton a páciens a 17, 15, 13 és a 23,25, 27 fogakon elhorgonyzott fémvázas kemény akrilát leplezésű fogpótlásokat, az alsó állcsonton a 43 fogon egy fémkoronát viselt. A páciens alsó kivehető fogpótlást nem viselt. A 21 és a 33 fogak gyári fémcsappal és kompozit töméssel voltak ellátva. Az 11, 21, 22 fogakról készült periapikális röntgenfelvételen a gyökértömések hossza megfelelő volt, de kondenzáltságuk és falállóságuk nem. (3. ábra)

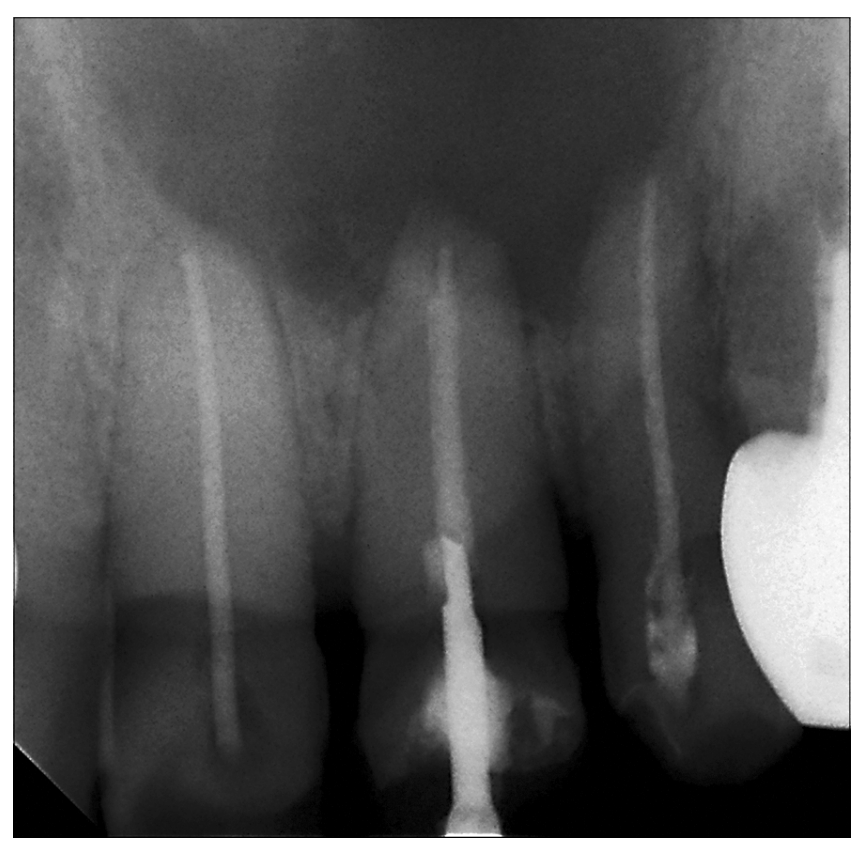

3. ábra: Kiindulási periapicalis röntgenfelvétel (2010. május 3.)
A 11 és 22 fogak fedőtömése hiányzott, a gyökértömések a szájüreggel érintkeztek. A fogak kopogtatásra érzékenyek voltak, leginkább a 21 fog.

A páciens röntgenleletei, tünetei és a beutaló orvossal való konzultáció után felállítottuk a kezelési tervet. A kezelési tervben a 11, 21, 22 fogak gyökértömésének eltávolítása, több ülésben elvégzett gyökérkezelésük, laterálkondenzációs technikával kivitelezett gyökértömésük, cisztektómia mütét és a 21, 22 fogak gyökércsúcs-rezekciója szerepelt.

Az Arc-, Állcsont-, Szájsebészeti és Fogászati Klinikán a páciens tüneteinek enyhítésére, a ciszta további növekedésének megelőzése érdekében már elvégeztek egy dekompressziós mútétet 2010 márciusában. A cisztán kialakított nyílásba egy jodoformos gézcsíkot helyeztek, ami biztosította a ciszta tartalmának folyamatos ürülését. A mútétet végző szájsebész a gézcsíkot rendszeresen cserélte, a ciszta üregét fiziológiás sóoldattal öblítette át. A páciens számára készült egy cisztaszűkítő 2010 májusában, ami egy akrilát alaplemezből és a ciszta üregébe vezető rugalmas müanyagcsőből állt. Ez a készülék folyamatos drenázst biztosít és célja a ciszta méretének olyan mértékü csökkentése, hogy a cisztektómia műtét elvégezhető legyen.

A cisztaszűkítőt a páciens a cisztektómia mútéte elötti hétig viselte, közben a rendszeres szájsebészeti kontrollok alkalmával a múanyag cső redukciójára is sor került. A cisztaszűkítő eltávolítása után a nyálkahártya gyógyulását követően került sor a műtétre. Az első gyökérkezelés alkalmával a 21 fogból a kompozit tömés és egy gyári fém gyökércsap, majd a gyökértömés a 11, 21, 22 fogakból kofferdam izolálásban, kloroform és Hedström reszelők segítségével sikeresen eltávolításra került. A gyökércsatornák átöblítésére 2,5\%-os nátrium-hipoklorit oldatot használtunk. A 21 fogból véres-gennyes váladék ürült. $A$ gyökércsatornák alapos átöblítése után, ideiglenes lezárásukhoz kálciumhidroxid pasztát használtunk. A cisztaszűkítő viselése alatt a fogakat 2-3 hetente kofferdam izolálásban megnyitottuk, gyökércsatornájukat nátrium-hipoklorit oldattal átöblítettük, kálcium-hidroxiddal és üvegionomer tö mőanyaggal lezártuk. Ennek több oka is volt: részben a 21 fog sokáig nem volt kiszárítható, mert a gyökércsatornán keresztül a cisztából folyadék ürült, másrészt a szakirodalom szerint a kálcium-hidroxid paszta $\mathrm{pH}$-értéke, kálcium-ion tartalma és antibakteriális hatása miatt kifejezetten jótékony hatású a periapikális szövetek gyógyulására $[4,10,15]$. A második kezelés alkalmával tűs kontroll-felvételek segítségével meghatároztuk a munkahosszokat és a csatornákat, Kerr reszelőkkel a 11, 21-es fogakat ISO 40-es méretig, a 22-es fogat 35-ös méretig tágítottuk. (4. ábra) Ezután minden kezelés alkalmával kofferdam izolálásban, vékony Kerr reszelők segítségével eltávolítottuk a kalcium-hidroxid pasztát, nátrium-hipoklorit oldattal alaposan átöblítettük a fogakat, papírcsúcsokkal kiszárítottuk és újra lezártuk. Mivel a fogak gyökértömését csak 

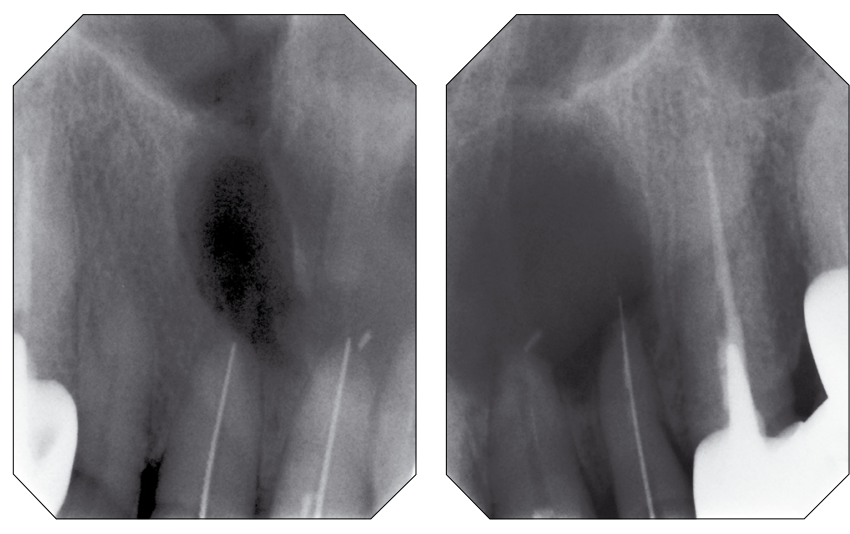

4.1 és 4.2 ábra: 11, 21 és 22 fogak tűskontroll felvételei

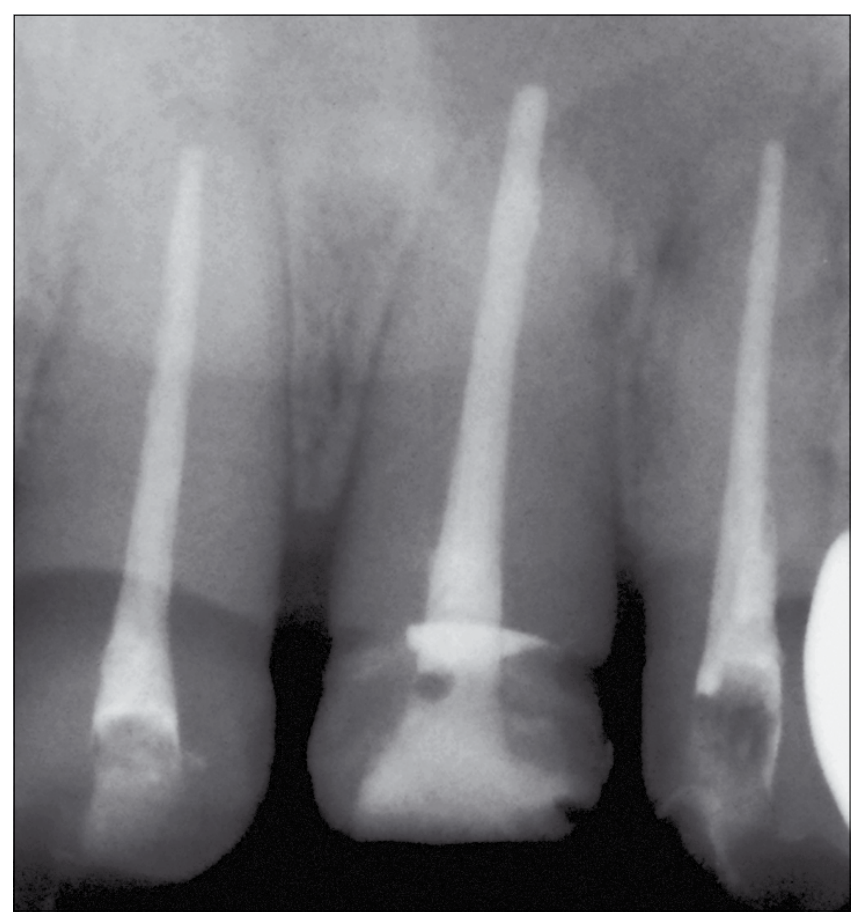

5. ábra: Gyökértömés kontroll felvétele
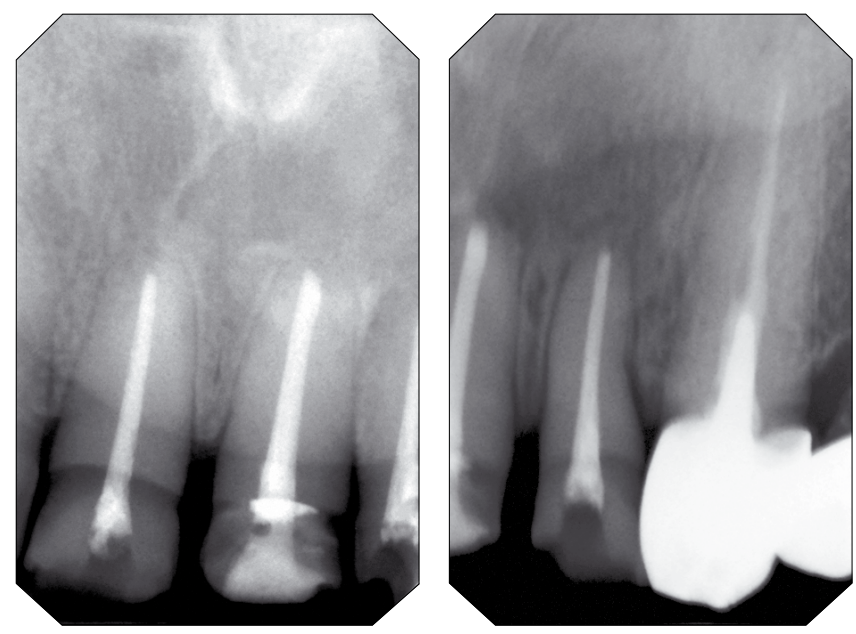

6.1 és 6.2 ábra: Periapicalis felvétel a gyógyult állapotról (2011. december 3.)

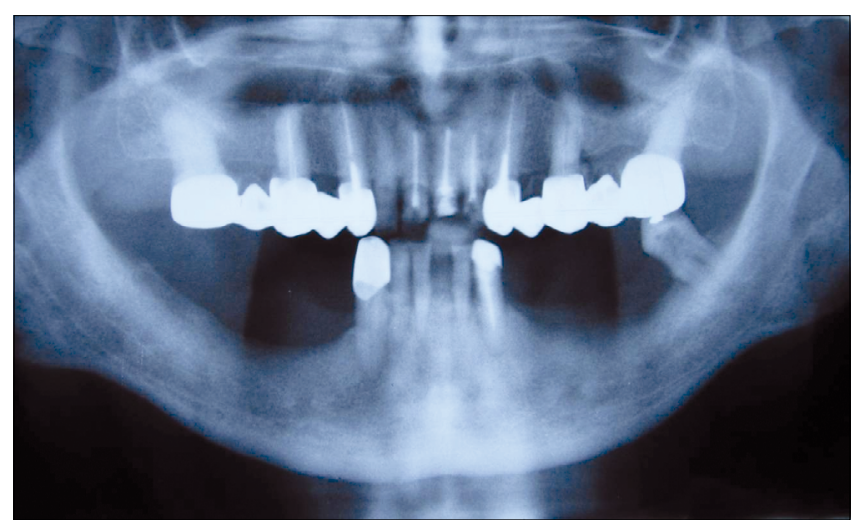

7. ábra: OP felvétel a gyógyult állapotról (2011. március 8.)

a cisztektómia mútét előtt egy nappal végeztük el (2010 október), így elkerülhető volt, hogy a gyökértömés esetlegesen a foramen apicalén keresztül fertőződjön. A mester fileom az 11, 21 fogaknál az 55-ös, a 22 fognál az 50-es Kerr reszelő volt. A step back technika alkalmazásával a 11 és 21 fogakat ISO 70-es méretig, a 22 fogat 60 -as méretig tágítottuk. A végső tágítás után a csatornákat újra átöblítettük nátrium-hipoklorit oldattal és végül desztilálltvízzel. A csatornák szárítását papír-csúcsokkal végeztük. A laterál kondenzációs technika alkalmazása során a gyökér tömésénél $A H$ Plus (Dentsply, DeTrey Gmbh) gyökértömő pasztát és guttaperhacsúcsokat használtunk. (5. ábra) A gyökértöméseket üvegionomer-cementtel zártuk le (Ketac Bond, 3M ESPE), a trepanációs nyílásokat pedig kompozit töméssel láttuk el. A gyökértömés kontroll röntgenfelvételén (2010 október) a kiindulási periapikális felvételhez képest (2010 május) nagymértékủ javulás, a ciszta méretének jelentős csökkenése látható. A kezelés teljes időtartama alatt a pácienst az Arc-, Állcsont-, Szájsebészeti és Fogászati Klinikán is követték, a ciszta méretét OP felvételeken ellenőrizték. A cisztektómia mútétre a Arc-, Állcsont-, Szájsebészet és Fogászati Klinikán 2010 októberében került sor. A szövettani vizsgálat a feltételezett diagnózist igazolta. Az első OP felvétel után 10 hónappal később készített röntgenképen az elváltozás már nem látható, (7. ábra) és a másfél évvel később készített periapikális felvételen (6. ábra) már a gyökérhártya-rajzolat is épnek látszik. $A$ páciens sem spontán, sem ingerekre jelentkező fájdalomról nem számolt be. A fogak a szájvizsgálat során sem kopogtatásra, sem a gyökércsúcs környékének enyhe nyomására nem voltak érzékenyek. A cisztektómia mútét után az érintett fogakat ideiglenes jelleggel, a ciszta teljes gyógyulásáig, kompozit töméssel állítottuk helyre.

A $12,11,21,22$ fogak végleges ellátása fémkerámia-koronákkal történt. Esztétikai megfontolásból a 12 fogra is borító korona készült. A csonk előkészítése során chamfer vállas, szupragingivális preparálást alkalmaztunk. (8. ábra) A lenyomatvétel előtt a csonkoknál ínybarázda tágítást végeztünk. (9. ábra) A pre- 


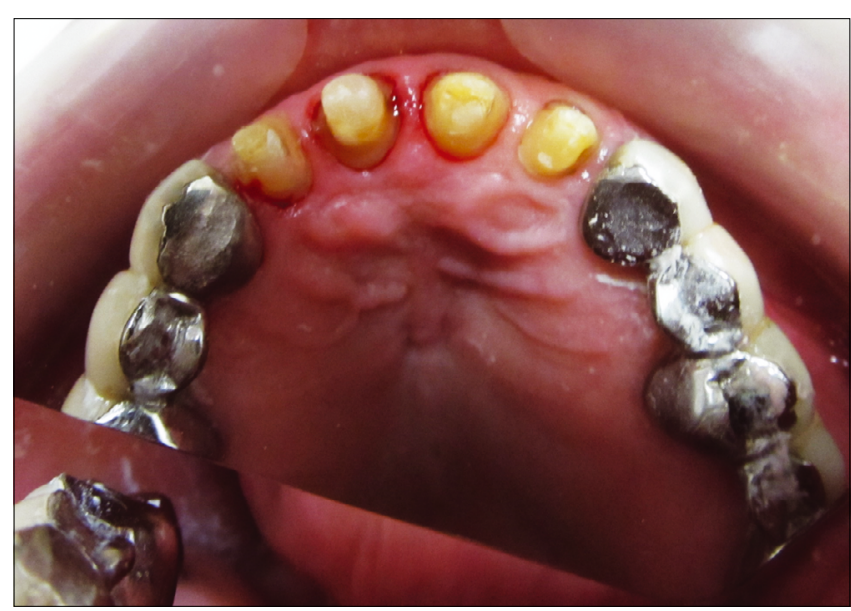

8. ábra: Előkészített fogak $(12,11,21,22)$

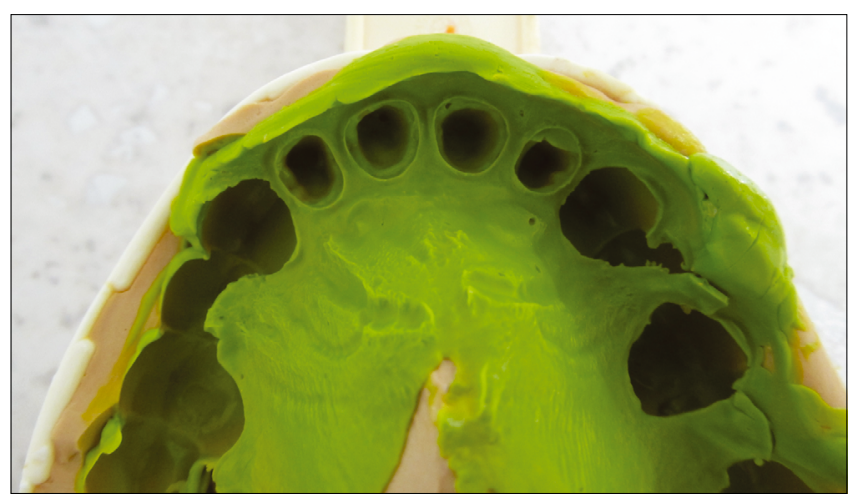

9. ábra: Precíziós-szituációs lenyomat

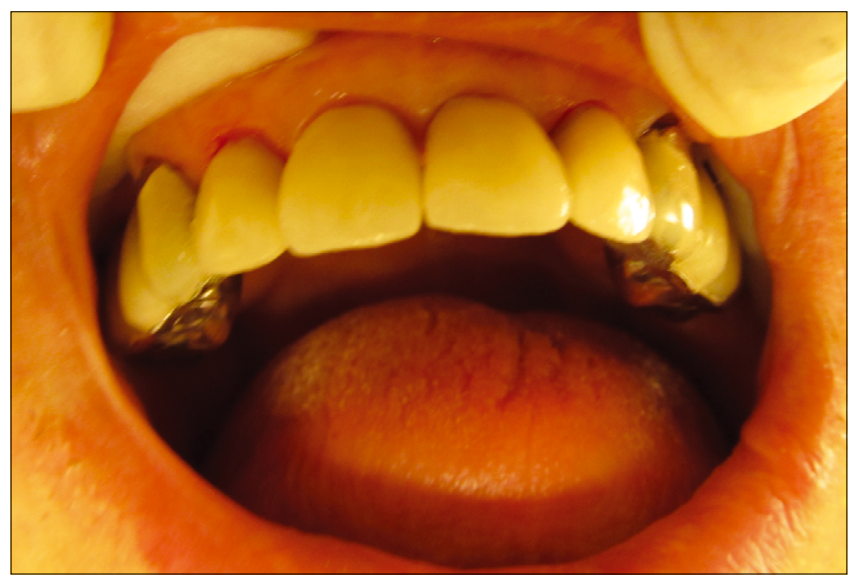

10. ábra: Kész fogpótlás

cíziós lenyomathoz A-szilikont (Coltene/Whaledent HydroXtreme) használtunk. A lenyomatanyag alap és korrekciós fázisát külön időben alkalmaztuk. A koronavázak nikkelmentes kobalt-króm-ötvözetből készültek. A koronákat a csonkokon Ketac Cem-mel (3M ESPE) rögzítettük. (10. ábra) A továbbiakban a felső oldalsó hidak cseréjét és az alsó állcsont fogpótlástani rehabilitációját terveztük. (11. ábra)

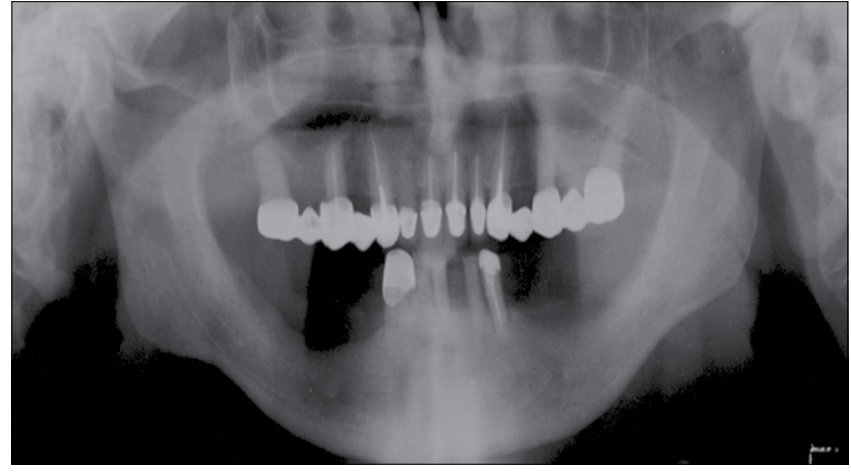

11. ábra: Op felvétel a felső pótlás átadása után

\section{Összefoglalás}

A bemutatott eset komplex szájsebészeti és endodonciai ellátást igényelt. A kezelési tervet a szájsebész kollégával együttműködve állítottuk fel, az egyes kezeléseket összehangolva. A komplex ellátás sikeres volt, a csontban lévő nagyméretű defektus körülbelül egy év alatt teljesen meggyógyult. A páciens protetikai rehabilitációjára csak a teljes gyógyulás után került sor. Esetünket azért tartottuk közlésre érdemesnek, mert meggyőző bizonyítéka annak, hogy korrekt endodonciai-szájsebészeti együttmüködéssel egy idősebb, cukorbeteg páciensnél, a ciszta által érintett fogai megtartása mellett is tökéletes gyógyulást eredményez.

\section{Irodalom}

1. Açıkgöz A, Uzun-Bulut E, Özden B, Gündüz K: Prevalence and distribution of odontogenic and nonodontogenic cysts in a Turkish Population. Med Oral Patol Oral Cir Bucal 2012; 17 (1): 108115.

2. Prockt AP, Schebela CR, Maito FdM, Sant'Ana-Filho M, Rados PV: Odontogenic Cysts: Analysis of 680 Cases in Brazil. Head and Neck Pathol 2008; 2: 150-156.

3. SzABó Gy: Szájsebészet. Semmelweis, Budapest, 2004; 69-84.

4. Gangwar A: Antimicrobial effectiveness of different preparations of calcium hydroxide. Indian J Dent Res 2011; 22: 66-70.

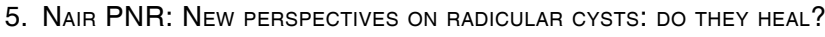
REVIEW. International Endodontics Journal 1998; 31: 155-160.

6. NAIR PNR, Sundovist G, SJöGREN U: Experimental evidence supports the abscess theory of development of radicular cysts. Surg Oral Med Oral Pathol Oral Radiol Endod 2008; 106: 294-303.

7. Németh Zs, Bogdán S: Állcsontcysták. Dental Hírek 2009; 2: 42-44.

8. MARTon R, SubA Zs: Az állcsontcysták epidemiológiai vizsgálata. Magyar Fogorvos 2009; 4: 174-175.

9. ShARIFIAN J M, KhALILI M: Odontogenic cysts: a retrospective study of 1227 cases in an Iranian population from 1987 to 2007. Journal of Oral Science 2011; 53(3): 361-367.

10. Soares JA, Britol-Junior M, Silceira FF, Nunes E, Santos SMC: Favorable response of an extensiv periapical lesion to root canal treatment. Journal of Oral Science 2008; 50(1): 107-118.

11. SuBA Zs: A szájüreg klinikai pathologiája. Medicina, Budapest, 1999; 228-238.

12. TANDRI SB: Management of infected radicular cyst by surgical decompression. J Conserv Dent. 2010 ; 13(3): 159-161.

13. Torres-Lagares $D$, Segura-Egea JJ, Rodríguez-Caballero A, Llamas-Carreras JM, Gutiérrez-Pérez JL: Treatment of a large 
maxillary cyst with marsupialization, decompression, surgical endodontic therapy and enucleation. J Can Dent Assoc 2011; 77-87.

14. Tortorici S, Amodio E, Massenti FM, Buzzanca ML, Burrunao F, VITALE F: Prevalence and distribution of odontogenic cysts in Sicily: 1986-2005. Journal of Oral Science, 2011; 53 (3), 361367.
15. VALOIS C RA, COSTA-JÚNIOR E D: Periapical cyst repair after nonsurgical endodontic therapy - Case report. Braz Dent J 200516 (3): 254-258.

16. BARABÁS J, ÚJPÁL M: A maxillofacialis régió állcsonti és lágyrész cystái. In: Barabás J, Orosz M: Szájsebészet és fogászat - Általános orvosok és orvostanhallgatók számára. Semmelweis, Budapest, 2012; 149-156.

\section{Szekeres Gy, Würsching T, Nemes J, Tóth Zs}

\section{Complex treatment of a large radicular cyst in the anterior region of the maxilla}

Case report

As opposed to other odontogenic cysts, the radicular cyst is always produced by intraradicular infection, therefore it is important to eliminate the cause of the inflammation as well. During the healing of the radicular cyst, the infected tooth should be treated by extraction or root canal treatment completed by surgical intervention. The presented case is a 77 year-old male patient with Type II Diabetes, who required oral surgery and endodontic treatment. Despite of the age and diabetes of the patient, the bone regeneration was rapid and complete. Seven months after starting the treatment, the size of the cyst decresed significantly and by 12th month it was perfectly healed.

Key words: rootcanal treatment, radicular cyst, cystectomy, decompression surgery, cystostomy 